\title{
PENILAIAN INSTALASI PENGOLAHAN LUMPUR TINJA (IPLT) DI BEBERAPA KOTA DI INDONESIA DENGAN MENGGUNAKAN ANALISA FAKTOR
}

\section{ASSESMENT ON SEPTAGE TREATMENT FACILITY IN INDONESIAN CITIES BASED ON FACTOR ANALYSIS}

\author{
Fitrijani Anggraini1) dan Reni Nuraeni2) \\ 1, 2)Pusat Litbang Perumahan dan Permukiman, Balitbang,Kementerian PUPR \\ Jalan Panyaungan, Cileunyi Wetan, Kabupaten Bandung \\ Email: fitrijania@yahoo.com
}

Diterima: 2 Desember 2015; Direvisi: Desember; Disetujui: 12 April 2016

\begin{abstract}
ABSTRAK
Masalah pencemaran air merupakan masalah yang rumit. Banyak faktor yang mempengaruhi keberhasilan upaya pengendalian pencemaran air. Pembangunan dan pengoperasian Instalasi Pengolahan Lumpur Tinja (IPLT) adalah salah satu wujud upaya pengendalian pencemaran dari sumber pencemaran yang berasal dari kegiatan perumahan dan permukiman. Keberhasilan pengelolaan IPLT tidak dapat hanya dilihat dari aspek fisik bangunan saja. Aspek lain seperti kualitas hasil olahan (effluent), pasokan lumpur tinja, kapasitas menganggur (idle), laju beban limbah permukaan dan volumetrik, sumber daya manusia, organisasi, standar prosedur operasi (SOP), tarif retribusi dan lain-lain adalah beberapa aspek yang harus menjadi acuan pengambilan keputusan untuk mengelola IPLT yang lebih baik. Kajian ini ditujukan untuk memberi gambaran aplikasi metode analisis faktor untuk menyelesaikan masalah IPLT yang kompleks dengan menemukenali penyebab utama dan merumuskan solusinya. Analisis faktor adalah salah satu pengambilan keputusan dengan banyak kriteria. Data dari 8 (delapan) IPLT kota studi digunakan acuan analisis. Kajian menyimpulkan bahwa Analisis Faktor mampu mengelompokkan 12 indikator menjadi 3 faktor tanpa mengurangi makna indikator pembentuknya sehingga mempermudah proses pengambilan keputusan. Pasokan lumpur tinja secara terjadwal, kejelasan pembagian tugas dan tanggung jawab, dan ketersediaan, kekinian, kemudahan akses dan kemudahan memahami SOP menjadi faktor penentu keberhasilan IPLT dalam pengendalian pencemaran limbah domestik.
\end{abstract}

Kata Kunci: Permukiman, pencemaran air, IPLT,analisis faktor, pengambilan keputusan

\begin{abstract}
ABSTRAK
The problem of water pollution is complex. There are many factors that influence the successfull of efforts for water pollution control. The construction and operation of septage treatment facility (IPLT) is an efforts for controlling pollution from domestic activities. The successfull of IPLT management cannot be assessed from physical aspect of the building only. Other aspects such as quality of effluent, sludge supply, idle capacity, the rate of surface loading and volumetric loading, human resources, organization, standard operating procedures (SOP), the tariff and others should be consider for decision making to manage IPLT better. The purpose of this study is to describe the application of factor analysis method to solve a complex problem of IPLT through identifying the main causes and formulate solutions. Factor analysis is one of decision with multicriteria. The primary data research in 2014 used as reference for analyzing. The conclusion of this study is the factor analysis is able to classify 12 indicators into 3 factors without reducing the meaning of the constituent indicator, thus simplifying the decision-making process. Significant factors that affecting the successfull of IPLT performance in controlling water pollution are : continuity of sludge supply, clarity of roles and responsibilities, availability, novelty, accesibility and simplicity of SOP.
\end{abstract}

Keywords: Settlements, water contamination, septage treatment facility, analysis factor, decision maker 


\section{PENDAHULUAN}

Sampai dengan akhir tahun 2013, akses masyarakat terhadap sanitasi layak yang berkelanjutan baru mencapai $60,91 \%$. Fakta ini menjadi landasan untuk terus meningkatkan berbagai upaya perbaikan pelayanan dan akses sanitasi, sehingga target pelayanan sektor air limbah sebesar 100\% pada tahun 2019 dapat dicapai.

Keberhasilan pengoperasian IPLT masih menghadapi tantangan yang cukup besar karena pencemaran air yang semakin meningkat. Pencemaran limbah domestik dinilai menjadi penyebab utama pencemaran limbah domestik sehingga mempengaruhi upaya penyediaan sumber air baku yang aman. Penelitian yang telah dilakukan di sungai Ciliwung, menyimpulkan bahwa sebesar $40 \%$ pencemaran berasal dari air limbah domestik yang dibuang ke sungai tanpa diolah terlebih dahulu. Beban cemaran yang masuk diperhitungkan mencapai 96 ton/hari dan total koli sebesar $7 \times 10^{4} \mathrm{MPN} / 100 \mathrm{~mL}$. Salah satu penyakit yang ditimbulkan akibat penurunan kualitas air karena pencemaran air limbah tersebut adalah diare. Pada tahun 2012 tercatat sebanyak 1.585 kasus penyakit diare dengan tingkat kematian (case fatality rate) sebesar 1,45\% (Kemenkes, 2013).

Untuk menanggulangi permasalahan tersebut, berbagai upaya pembangunan fisik telah dilakukan oleh pemerintah pusat maupun pemerintah daerah. Direktorat Pengembangan Penyehatan Lingkungan Permukiman-Ditjen Cipta Karya-Kementerian PU menetapkan rencana kegiatan sesuai Rencana Kerja Pemerintah (RKP) yang mengacu pada Peraturan Presiden No. 43/2014. Diantaranya pada tahun 2012, telah dilakukan peningkatan pelayanan infrastruktur air limbah sistem setempat dan sistem terpusat (on site dan off site) di 358 kawasan. Sementara pada tahun 2013, telah dilakukan peningkatan kinerja infrastruktur air limbah di 567 kawasan, dan rehabilitasi IPLT di 18 kota/kabupaten.

Upaya peningkatan kinerja IPLT juga telah dilakukan terhadap 146 unit IPLT yang tersebar di 23 propinsi (dari 33 propinsi) di Indonesia. Kapasitas IPLT yang ditingkatkan kinerjanya terdiri dari 2 (dua) ukuran yaitu ukuran sedang dan kecil (kapasitas $<100 \mathrm{~m}^{3}$ /hari) dibangun di kota sedang dan kecil. Ukuran besar (kapasitas > $100 \mathrm{~m}^{3} /$ hari) dibangun di kota besar dan metropolitan. Adapun target upaya peningkatan kinerja IPLT tersebut adalah terkendalinya pencemaran air akibat limbah tinja hingga sebesar $45 \%$ dari total beban cemaran yang memenuhi standar kualitas air kategori II. (Direktorat PPLP, Dirjen Cipta Karya, 2013)
Permasalahan pencemaran limbah tinja dan kinerja IPLT telah mendorong dilakukannya berbagai penelitian. Kajian teknis melalui program bantuan teknis telah dilaksanakan oleh Ditjen Cipta Karya, Kementerian Pekerjaan Umum selama tiga tahun berturut-turut yaitu tahun 2010, 2011, dan 2012. Tujuannya adalah untuk menilai kondisi pengoperasian IPLT dan memilih lokasi IPLT yang layak menerima bantuan dari pemerintah pusat.

Kajian tersebut menyimpulkan bahwa IPLT di Indonesia belum beroperasi secara maksimal. Beberapa kendala yang dihadapi antara lain adalah kurangnya pasokan lumpur tinja yang masuk ke IPLT, manajemen IPLT yang belum profesional, rendahnya pengetahuan masyarakat mengenai pengolahan lumpur tinja, keengganan masyarakat untuk membayar retribusi pelayanan air limbah dan bisnis penyedotan lumpur tinja yang belum menarik investor. Belum optimalnya pengelolaan IPLT di daerah memerlukan komitmen berbagai pihak, baik pemerintah pusat, pemerintah daerah, swasta dan masyarakat penggunanya.

Solusi dan tindak lanjut hasil penelitian tersebut, umumnya masih terfokus pada masalah teknis misalnya aspek teknis perencanaan atau teknis operasional. Solusi masalah manajemen misalnya masalah kelembagaan atau masalah keuangan dilakukan secara terpisah dari aspek teknisnya. Akibatnya, solusi untuk menyelesaikan masalah menjadi tidak efektif, karena belum menyentuh akar permasalahan yang dihadapi. Fakta-fakta tersebut memberi indikasi kompleksitas pada skala pengoperasian IPLT.

Berdasarkan hal tersebut, pada tahun 2014 Pusat Penelitian dan Pengembangan Permukiman melakukan penelitian pemetaan teknologi IPLT yang lebih komprehensif yang memperhitungkan unsur teknis (technoware), unsur manusia (humanware), unsur informasi (infoware) dan unsur organisasi (orgaware). Penelitian ini mempertimbangkan kondisi sistem di hulu dan di hilir, status rehabilitasi dan kondisi operasional IPLT serta kualitas olahan pada input maupun output IPLT. Tujuan penelitian tersebut adalah untuk memetakan kondisi pemanfaatan IPLT, keandalan komponen teknologi IPLT, kontribusi komponen teknologi IPLT dalam mengolah limbah tinja yang masuk.

Makalah ini bertujuan untuk mengetahui faktor dominan yang berpengaruh pada kinerja IPLT, sehingga perbaikan kinerja IPLT akan difokuskan pada perbaikan sub variabel tersebut. Hal ini akan mempermudah pengambilan keputusan untuk pengendalian pencemaran limbah domestik. 


\section{KAJIAN PUSTAKA}

Kompleksitas masalah terindikasi dari jumlah dan keragaman faktor penyebab masalah. Hal tersebut menjadi landasan penggunaan metode pengambilan keputusan berbasis pada kriteria majemuk (multi criteria). Metode dan teknik analisis pengambilan keputusan yang digunakan juga bervariasi tergantung pada jenis masalah yang dihadapi, ketersediaan data, kemudahan akses ke perangkat lunak, kemudahan interpretasi hasil analisis dan pemahaman penguna teknologi.

Beberapa metode dan teknik analisis dan evaluasi masalah yang biasa digunakan untuk membantu proses pengambilan keputusan misalnya metode Delphi, metode audit teknologi, metode SWOT (Strengths, Weakness, Opportunity, Threath), metode Analitycal Hierarkhy Process (AHP), metode dan teknik Bayes dan lain-lain. Teknik-teknik berbasis statistik yang biasa digunakan dalam proses evaluasi adalah metode statistika deskriptif. Menurut Chang, 1996 dikutip dari Hanien Nia H Shega, 2012, dalam AHP pengambilan keputusan dengan banyak kriteria bersifat subjektif. Selain itu para pengambil keputusan lebih yakin menentukan pilihannya terhadap tingkat kepentingan antar kriteria dengan memakai penilaian dalam interval dibandingkan penilaian dengan angka eksak.

Namun, penggunaan metode tersebut di bidang pengendalian pencemaran air umumnya terbatas pada pembuktian ada atau tidaknya hubungan diantara parameter-parameter yang diuji. Untuk mengatasi permasalahan tersebut, metode dan teknik statistik yang melibatkan banyak variabel adalah metode analisis komponen utama (principal komponen analysis), analisis faktor, metode regresi ganda, metode analisis determinan.

Pada tahun 1989, diagram Nation Economic and Social Commision for Asia dan Pasific (UNESCAP) mempublikasikan penerapan metode audit teknologi yang unsur-unsurnya meliputi unsur technoware, humanware, infoware dan orgaware (Kamaluddin, R. dkk, 2010). Pada awalnya, penerapan metode ini dipakai oleh sektor industri untuk acuan pengambilan keputusan terkait dengan peningkatan produksi, peningkatan penjualan. Pada perkembangan selanjutnya, penerapan metode audit teknologi atau atlas teknologi semakin luas memasuki berbagai sektor non industri.

Penerapan metode ini umumnya diawali dengan menilai derajat kecanggihan (sofistikasi) terakhir (state of the art) dari setiap komponen teknologi yang dinilai dengan menggunakan skala $=0$ (tidak canggih) sampai skala = 10 (sangat canggih). Skor kecanggihan teknologi merupakan angka rata rata dari jumlah bobot kriteria teknologi dikalikan skala nilai kecanggihan. Rumusnya adalah $1 / 10\left[\Sigma \mathrm{K}_{\mathrm{t}} \mathrm{x} \mathrm{T}_{\mathrm{ik}} / \mathrm{K}_{\mathrm{t}}\right]$, dimana $\mathrm{Kt}$ adalah komponen technoware ke $(\mathrm{t})$ dan Tik adalah skor atau bobot kriteria ke $\mathrm{k}$ untuk technoware ke i. Rumus yang sama digunakan untuk menilai kecanggihan atau "state of the art" unsur humanware, infoware dan orgaware. Selanjutnya, dihitung kontribusi komponen teknologi yaitu dengan menambahkan hasil perkalian skor kecanggihan dengan selisih batas atas dengan batas bawah dengan batas bawahnya. Rumusannya adalah $1 / 9$ [skor kecanggihan teknologi (batas atas-batas bawah) + batas bawah]. Rumus ini dipakai pula untuk menghitung kontribusi komponen teknologi lainnya (humanware, infoware, orgaware).

Dalam praktek di lapangan, penerapan metode atlas teknologi UNESCAP sangat beragam disesuaikan dengan tujuan, objek yang dikaji, ruang lingkup pemetaan, banyaknya indikator dan ketersediaan data sekunder dan keterbatasan memperoleh data primer. Aplikasi metode atlas teknologi tidak selalu sesuai dengan konsep aslinya. Teknik-teknik pengumpulan data, pemilihan variabel dan indikator teknologi, pengujian hubungan diantara variabel dan indikator memperkaya penggunaan metode atlas teknologi. Teknik Delphi, teknik statistik parametrik dan non parametrik selain digunakan untuk mengawali proses aplikasi metode atlas teknologi UNESCAP, seringkai juga dipakai untuk mempertajam analisis dan sintesis.

Despeise D. dkk, 2011 membahas aplikasi atlas teknologi untuk menilai komponen teknologi untuk berbagai jenis industri yang berbeda di suatu kawasan. Penilaian difokuskan pada identifikasi aplikasi strategi industri untuk memastikan keberlanjutan lingkungan dalam mendukung pembangunan berkelanjutan. Reza M. dkk, 2011, membahas aspek transfer teknologi. Statistika deskriptif digunakan untuk menguji hubungan variabel-variabel teknologi yang digunakan dalam proses trasformasi. Iwan I W dkk, 2011 menggunakan uji t (T-test) untuk menguji komponen teknologi sebelum menghitung kontribusi komponen technoware, humanware, infoware, orgaware (THIO) pada kinerja usaha kecil dan menengah (UKM), sebelum dilakukan analisis menggunakan "Structural Equation Model (SEM)". Abas T, Yaghoub A M, 2012; menggunakan uji T (T-test) dan uji F (F-test) terhadap "mean score" komponen teknologi dan kontribusi teknologi dalam mempromosikan dan memperbaiki kemampuan industri. 
Maryam E. dkk, 2013, menggunakan analisis faktor untuk mengkaji kemampuan teknologi baru industri petrokimia yang meliputi nano teknologi, bioteknologi, dan teknologi membran. Uji validasi dan uji reabilitas dilakukan dengan menggunakan dengan "Cronbach's Alpha". Retno I. dkk, 2014 menilai kecanggihan dan kontribusi teknologi industri sesuai dengan konsep USESCAP dengan pabrik pembanding. Sarono dkk, 2014, juga membahas penerapan atlas teknologi sesuai konsep UNESCAP untuk menilai kontribusi Instalasi Pengolahan Air Limbah (IPAL) Kelapa Sawit yang dibandingkan dengan IPAL kelapa sawit milik perusahaan lain.

Penelitian evaluasi ini menggunakan metode analisis faktor untuk mengidentifikasi sub variabel atau sub komponen teknologi yang dapat mempengaruhi kemampuan IPLT untuk pengendalian pencemaran limbah domestik.
Analisis bobot faktor dan skor faktor digunakan acuan untuk mengestimasi besarnya kontribusi IPLT pada pengendalian pencemaran limbah domestik.

\section{METODOLOGI}

Input data untuk analisis faktor berasal dari hasil penilaian kuantitatif, yang dihasilkan dari kegiatan penelitian dan pengembangan Peningkatan Sarana dan Prasarana Permukiman, tahun 2014. Input data terdiri dari 8 (delapan) unit IPLT yaitu: IPLT Tegal, IPLT Palu, IPLT Mojokerto, IPLT Banda Aceh, IPLT Tangerang, IPLT Buleleng, IPLT Klungkung dan IPLT Kulonprogo.

Alur pelaksanaan penelitian secara skematik dapat dilihat pada Gambar 1.

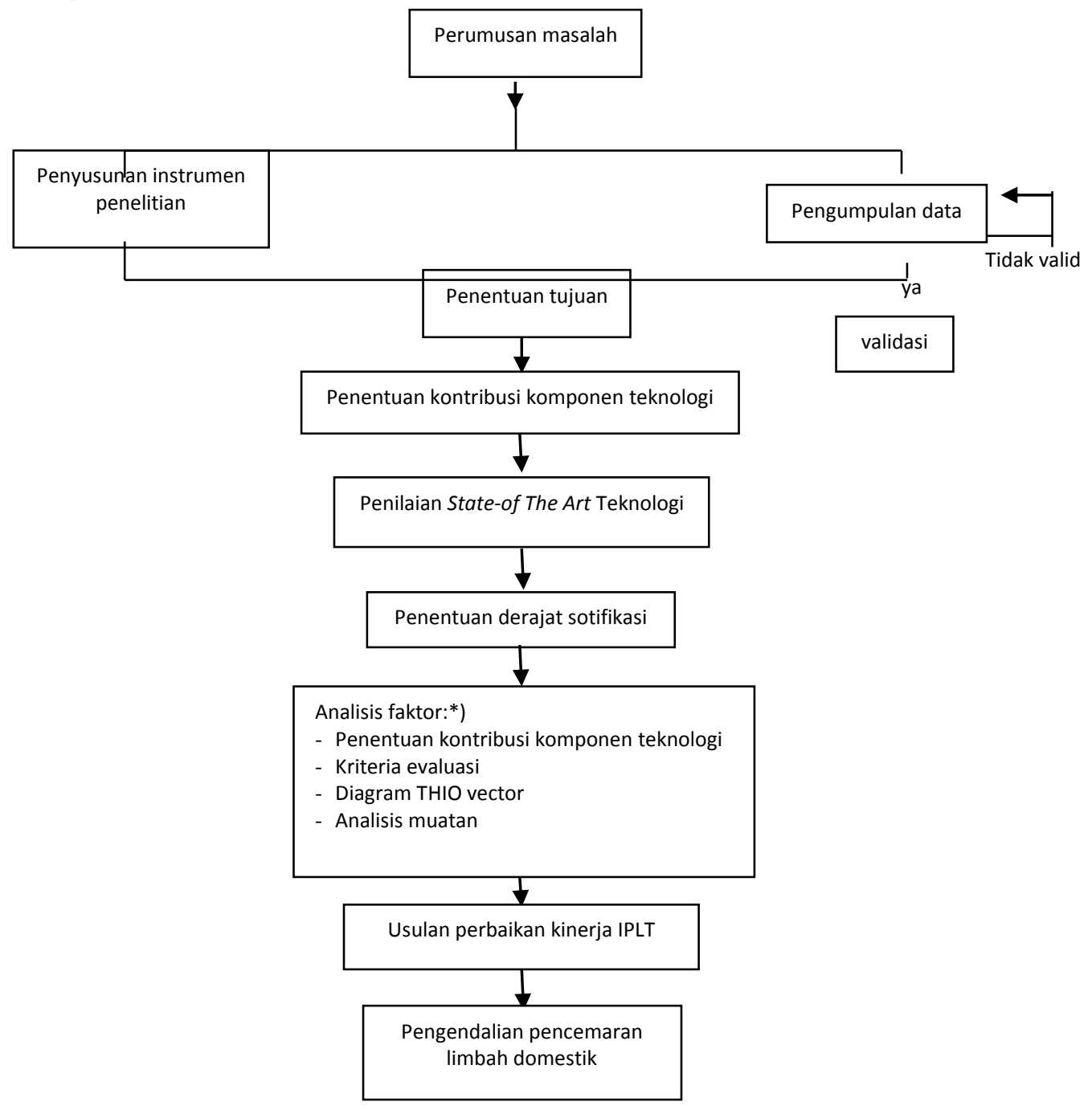

Keterangan: *) Pengolahan data regresi linier dengan software SPSS versi 18 sebagai alat bantu

Gambar 1 Diagram alir penelitian 
Langkah-langkah menyusun instrumen penelitian ini, adalah (1) Analisis variabel penelitian, yaitu mengkaji variabel menjadi sub penelitian sehingga indikatornya dapat diukur dan menghasilkan data yang akurat. Membuat indikator variabel, menggunakan teori ataupun konsep pengetahuan ilmiah yang relevan dengan variabel tersebut, atau dengan menggunakan fakta berdasarkan pengamatan secara langsung. (2) Penetapan penggunaan jenis instrumen dalam mengukur variabel, subvariabel, ataupun indikatornya. Setiap variabel dapat diukur dengan satu atau lebih jenis instrumen.

Kontribusi IPLT pada upaya pengendalian pencemaran limbah domestik dikaji dari kontribusi komponen teknologi pembentuk IPLT yang berjumlah 12 (dua belas) sub variabel. Dengan demikian, input data disusun dalam matrik pada Tabel 1 yang terdiri dari 8 (delapan) lajur x 12 (dua belas) kolom sel matrik = $96 \mathrm{sel}$ matrik yang masing-masing berisi data spesifik, lihat Tabel 1.

Persamaan analisis faktor untuk menjelaskan kontribusi komponen teknologi IPLT dalam pengendalian pencemaran limbah domestik adalah seperti persamaan (1).

Analisis faktor menggunakan perangkat lunak (software) SPSS versi-18 untuk menguji kekuatan hubungan diantara variabel komponen teknologi IPLT, mengestimasi variansi dari setiap variabel yang dapat dijelaskan oleh faktor yang terbentuk, mengidentifikasi faktor-faktor yang memenuhi kriteria nilai varians (eigenvalue) yang lebih besar dari 1,00 dan menentukan proporsi keragaman faktor terhadap keragaman total serta menentukan bobot faktor dan/atau skor faktor.

Dengan didapatnya nilai varians, bobot faktor dan skor faktor, maka Indeks komponen teknologi masing masing IPLT yang dinilai untuk setiap unsur technoware, humanware, infoware dan orgaware dihitung dengan menggunakan persamaan (2).
$Y_{j}=F_{j-1} V_{1-j}+F_{j-2} V_{2-j}+F_{j-3} V_{3-j \ldots} \ldots F_{j-n} V_{n-j}+F_{u}$

dimana,

$Y_{j} \quad$ : $\quad$ IPLT ke-j $(\mathrm{j}=1,2, \ldots, 8)$

$F_{j}:$ Bobot faktor atau Skor faktor komponen teknologi ke-j $(j=1,2, \ldots, 8)$

$V_{i} \quad: \quad$ Nilai komponen teknologi ke-i $(\mathrm{i}=1,2, \ldots$, 12)

$F_{u} \quad: \quad$ Faktor unik

$j \quad: \quad$ jumlah IPLT yang dinilai

$i \quad$ : Jumlah variabel komponen teknologi IPLT

$I_{j}=1 / \gamma_{k} \Sigma F_{j i} V_{i j}$

dimana,

$I_{j} \quad: \quad$ Indeks komponen teknologi IPLT

$\gamma_{k}$ : Nilai varians (eigenvalue) ke-k faktor yang terbentuk $(\mathrm{k}=1,2, \ldots, \mathrm{p})$

$F_{j i} \quad: \quad$ Bobot faktor atau skor faktor IPLT ke juntuk komponen teknologi i $(\mathrm{i}=1,2$, ..., n)

$V_{i j} \quad: \quad$ Nilai komponen teknologi ke-i untuk IPLT ke-j

i : Jumlah variabel komponen teknologi IPLT

$j \quad: \quad$ Jumlah IPLT yang dinilai

$K \quad$ : Jumlah faktor yang terbentuk

Selanjutnya, komponen dan sub komponen teknologi IPLT yang dinilai menjadi penyebab utama berkurangnya IPLT berkontribusi pada pengendalian pencemaran limbah domestik adalah komponen teknologi yang memiliki skor $\mathrm{x}$ nilai $\left(\mathrm{F}_{\mathrm{ji}}\right.$.Vij) lebih kecil dari rata rata dan dihitung dengan menggunakan persamaan (3).

$\left.K T R_{i j}=\operatorname{Min}\left[\left(\sum F_{j i} V_{i j}-1 / j \sum F_{j i} V_{i j}\right) / \sum F_{j i} V_{i j}\right] \times 100 \% . .3\right)$

Dimana,

$K T R_{i j} \quad$ : Komponen Teknologi rendah Kontribusi ke i untuk IPLT ke-j.

Tabel 1 Keterkaitan Antar Faktor Yang Berpengaruh

\begin{tabular}{c|c|c|c|c|c|c|c|c|c|c|c|c}
\hline & $\mathbf{V}_{\mathbf{1}}$ & $\mathbf{V}_{\mathbf{2}}$ & $\mathbf{V}_{\mathbf{3}}$ & $\mathbf{V}_{\mathbf{4}}$ & $\mathbf{V}_{\mathbf{5}}$ & $\mathbf{V}_{\mathbf{6}}$ & $\mathbf{V}_{\mathbf{7}}$ & $\mathbf{V}_{\mathbf{8}}$ & $\mathbf{V}_{\mathbf{9}}$ & $\mathbf{V}_{\mathbf{1 0}}$ & $\mathbf{V}_{\mathbf{1 1}}$ & $\mathbf{V}_{\mathbf{1 2}}$ \\
\hline IPLT $_{\mathbf{1}}$ & $\mathrm{V}_{1-1}$ & $\mathrm{~V}_{2-1}$ & $\mathrm{~V}_{3-1}$ & $\mathrm{~V}_{4-1}$ & $\mathrm{~V}_{5-1}$ & $\mathrm{~V}_{6-1}$ & $\mathrm{~V}_{7-1}$ & $\mathrm{~V}_{8-1}$ & $\mathrm{~V}_{9-1}$ & $\mathrm{~V}_{10-1}$ & $\mathrm{~V}_{11-1}$ & $\mathrm{~V}_{12-1}$ \\
\hline $\mathbf{I P L T}_{\mathbf{2}}$ & $\mathrm{V}_{1-2}$ & $\mathrm{~V}_{2-2}$ & $\mathrm{~V}_{3-2}$ & $\mathrm{~V}_{4-2}$ & $\mathrm{~V}_{5-2}$ & $\mathrm{~V}_{6-2}$ & $\mathrm{~V}_{7-2}$ & $\mathrm{~V}_{8-2}$ & $\mathrm{~V}_{9-2}$ & $\mathrm{~V}_{10-2}$ & $\mathrm{~V}_{11-2}$ & $\mathrm{~V}_{12-2}$ \\
\hline $\mathbf{I P L T}_{\mathbf{3}}$ & $\mathrm{V}_{1-3}$ & $\mathrm{~V}_{2-3}$ & $\mathrm{~V}_{3-3}$ & $\mathrm{~V}_{4-3}$ & $\mathrm{~V}_{5-3}$ & $\mathrm{~V}_{6-3}$ & $\mathrm{~V}_{7-3}$ & $\mathrm{~V}_{8-3}$ & $\mathrm{~V}_{9-3}$ & $\mathrm{~V}_{10-3}$ & $\mathrm{~V}_{11-3}$ & $\mathrm{~V}_{12-3}$ \\
\hline IPLT $_{\mathbf{4}}$ & $\mathrm{V}_{1-4}$ & $\mathrm{~V}_{2-4}$ & $\mathrm{~V}_{3-4}$ & $\mathrm{~V}_{4-4}$ & $\mathrm{~V}_{5-4}$ & $\mathrm{~V}_{6-4}$ & $\mathrm{~V}_{7-4}$ & $\mathrm{~V}_{8-4}$ & $\mathrm{~V}_{9-4}$ & $\mathrm{~V}_{10-4}$ & $\mathrm{~V}_{11-4}$ & $\mathrm{~V}_{12-4}$ \\
\hline IPLT $_{\mathbf{5}}$ & $\mathrm{V}_{1-5}$ & $\mathrm{~V}_{2-5}$ & $\mathrm{~V}_{3-5}$ & $\mathrm{~V}_{4-5}$ & $\mathrm{~V}_{5-5}$ & $\mathrm{~V}_{6-5}$ & $\mathrm{~V}_{7-5}$ & $\mathrm{~V}_{8-5}$ & $\mathrm{~V}_{9-5}$ & $\mathrm{~V}_{10-5}$ & $\mathrm{~V}_{11-5}$ & $\mathrm{~V}_{12-5}$ \\
\hline IPLT $_{\mathbf{6}}$ & $\mathrm{V}_{1-6}$ & $\mathrm{~V}_{2-6}$ & $\mathrm{~V}_{3-6}$ & $\mathrm{~V}_{4-6}$ & $\mathrm{~V}_{5-6}$ & $\mathrm{~V}_{6-1}$ & $\mathrm{~V}_{7-6}$ & $\mathrm{~V}_{8-6}$ & $\mathrm{~V}_{9-6}$ & $\mathrm{~V}_{10-6}$ & $\mathrm{~V}_{11-6}$ & $\mathrm{~V}_{12-6}$ \\
\hline IPLT $_{\mathbf{7}}$ & $\mathrm{V}_{1-7}$ & $\mathrm{~V}_{2-7}$ & $\mathrm{~V}_{3-7}$ & $\mathrm{~V}_{4-7}$ & $\mathrm{~V}_{5-7}$ & $\mathrm{~V}_{6-7}$ & $\mathrm{~V}_{7-7}$ & $\mathrm{~V}_{8-7}$ & $\mathrm{~V}_{9-7}$ & $\mathrm{~V}_{10-7}$ & $\mathrm{~V}_{11-7}$ & $\mathrm{~V}_{12-7}$ \\
\hline IPLT $_{\mathbf{8}}$ & $\mathrm{V}_{1-8}$ & $\mathrm{~V}_{2-8}$ & $\mathrm{~V}_{3-8}$ & $\mathrm{~V}_{4-8}$ & $\mathrm{~V}_{5-8}$ & $\mathrm{~V}_{6-8}$ & $\mathrm{~V}_{7-8}$ & $\mathrm{~V}_{8-8}$ & $\mathrm{~V}_{9-8}$ & $\mathrm{~V}_{10-8}$ & $\mathrm{~V}_{11-8}$ & $\mathrm{~V}_{12-8}$ \\
\hline
\end{tabular}

Sumber: Hasil analisis, 2015 
Akhirnya, IPLT yang termasuk kategori kurang berkontribusi pada pengendalian pencemaran limbah domestik adalah IPLT yang memiliki Indeks komponen teknologi $\left(\mathrm{I}_{\mathrm{j}}\right)$ lebih rendah dari $\mathrm{I}_{\mathrm{j}}$ rata rata dan dihitung dengan menggunakan persamaan (4).

IPLT $\mathrm{R}_{\mathrm{j}}=\operatorname{Min}\left[\left(\mathrm{I}_{\mathrm{j}}-1 / \mathrm{i} \quad \sum \mathrm{Ij}\right) / \mathrm{Ij}\right] \quad \mathrm{x} \quad 100 \% \quad \ldots$ (4) Dimana,

IPLT-R $\quad$ : IPLT kontribusi Rencah ke-j.

\section{HASIL DAN PEMBAHASAN}

\section{Korelasi komponen Teknologi IPLT}

Di bagian awal tulisan ini disebutkan bahwa komponen teknologi meliputi 4 (empat) variabel yaitu: technoware (perangkat teknis), humanware (perangkat manusia), infoware (perangkat informasi) dan orgaware (perangkat organisasi). Perangkat teknis (technoware) IPLT dibagi menjadi 3 (tiga) sub variabel yaitu: (1) kualitas olahan, (2) desain unit bangunan dan (3) fungsi IPLT. Perangkat manusia (humanware) dibagi 2 (dua) sub variabel yaitu: (1) jumlah SDM dan (2) kompetensi SDM. Perangkat informasi (infoware) atau SOP dibagi 4 (empat) sub variabel yaitu: (1) kelengkapan, (2) kekinian, (3) kemudahan mengakses dan (4) kemudahan memahami. Perangkat organisasi dibagi 3 (tiga) sub variabel yaitu: (1) tugas dan tanggung jawab, (2) kerjasama dan (3) keuangan. Korelasi komponen teknologi diketahui dari nilai koefisien sub variabel dan tanda + (selaras) dan tanda (bertentangan). Sebagaimana tertera pada Tabel 2 , tidak semua sub variabel komponen teknologi IPLT memiliki hubungan yang kuat dan positif.
Kualitas olahan (OLAH) berkorelasi positif dan kuat dengan desain unit bangunan (KRIT), jumlah SDM (JSDM), kerjasama (KJSM). Hal ini mengindikasikan bahwa peningkatan mutu efluen IPLT memerlukan peningkatan kualitas operasi dan pemeliharaan bangunan pengolahan. Selain itu diperlukan pula peningkatan jumlah SDM dan kerjasama dengan swasta maupun satuan kerja pemerintah daerah (SKPD) lainnya. Kompetensi SDM (KSDM) berkorelasi negatif dengan kelengkapan, kemudahan akses dan kemudahan memahami SOP yang ada. Hal ini mengindikasikan bahwa apabila SOP sudah memadai maka tidak diperlukan upaya peningkatan kompetensi SDM.

Dengan demikian kuatnya korelasi diantara sub-sub variabel perawatan bangunan yang memadai, jumlah SDM yang cukup, kerjasama yang saling menguntungkan, kompetensi SDM dan kualitas SOP berpotensi memperkuat dukungan IPLT pada pengendalian pencemaran limbah domestik.

\section{Komunalitas dan Variansi Komponen Teknologi IPLT}

Analisis komunalitas (communalities) ditujukan untuk memperkirakan atau mengestimasi variansi setiap sub variabel yang dijelaskan oleh faktor-faktor yang terbentuk atau yang telah terekstraksi. Sebagaimana tampak pada Tabel 3 faktor yang terbentuk (terekstraksi) dari 12 (dua belas) sub variabel berjumlah 3 (tiga) faktor. Estimasi variansi yang dijelaskan oleh ketiga faktor yang terbentuk cukup tinggi dengan nilai rata-rata di atas 90\%. Dengan demikian, maka ketiga faktor tersebut telah mewakili sub-sub variabel pembentuknya.

Tabel 2 Koefisien Korelasi Komponen Teknologi IPLT

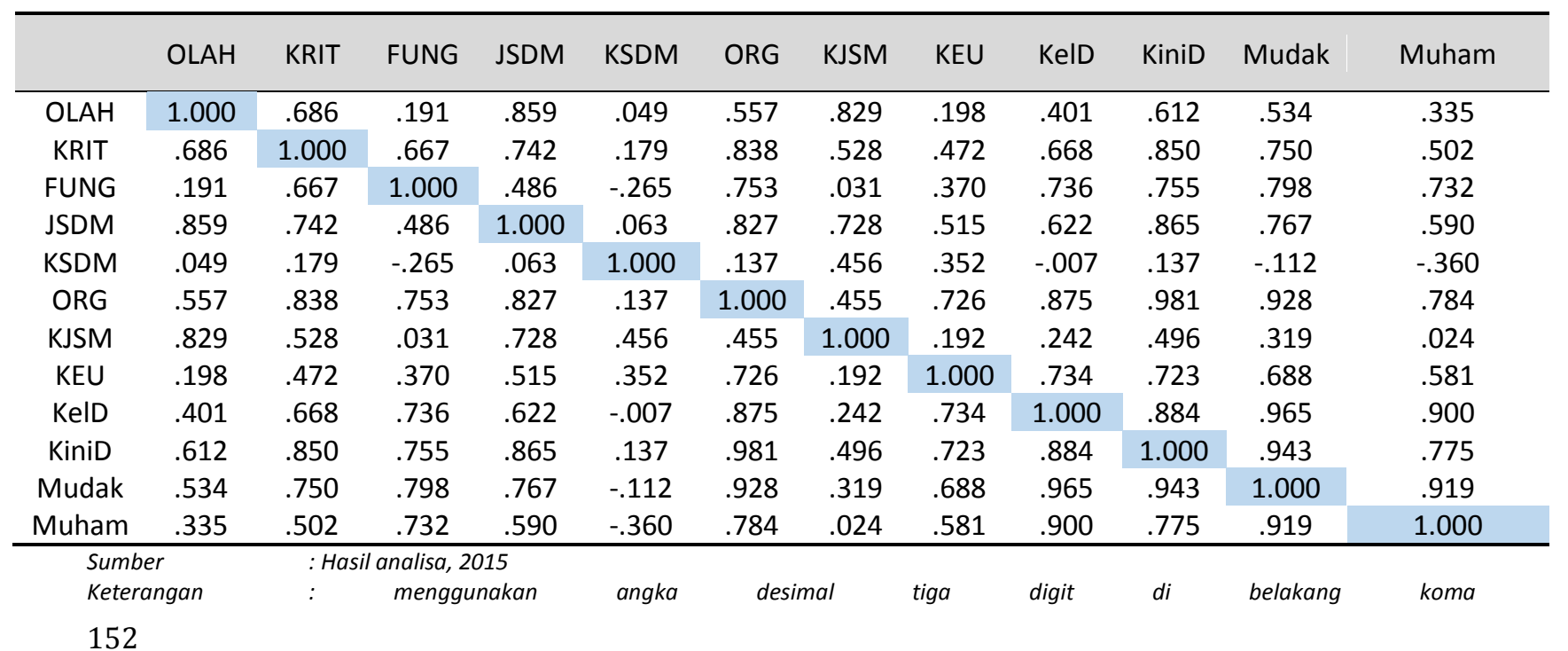


Tabel 3 Komunalitas dan Variansi Komponen Teknologi IPLT

\begin{tabular}{lccccc}
\hline \multirow{2}{*}{ Variabel } & Sub & \multicolumn{2}{l}{ Faktor Komponen Teknologi IPLT } & \multirow{2}{*}{ Komunalitas } \\
\cline { 3 - 5 } Variabel & Faktor-1 & Faktor-2 & Faktor-3 & \\
\cline { 3 - 5 } Techoware & OLAH & .660 & .543 & -.470 & .952 \\
& KRIT & .852 & .197 & -.064 & .769 \\
& FUNG & .745 & -.463 & -.087 & .777 \\
\hline \multirow{2}{*}{ Humanware } & JSDM & .873 & .317 & -.238 & .919 \\
& KSDM & .058 & .673 & .704 & .952 \\
\hline \multirow{4}{*}{ Infoware } & KelD & .906 & -.270 & .164 & .921 \\
& KiniD & .990 & .020 & .078 & .987 \\
& Mudak & .967 & -.227 & -.014 & .986 \\
& Muham & .813 & -.503 & -.077 & .919 \\
\hline \multirow{2}{*}{ Orgaware } & ORG & .975 & -.015 & .113 & .964 \\
& KJSM & .502 & .810 & -.170 & .936 \\
& KEU & .700 & -.051 & .605 & .859 \\
\hline
\end{tabular}

Sumber: Hasil analisa, 2015

Tabel 4 Rotasi Komunalitas dan Varians Komponen Teknologi IPLT

\begin{tabular}{|c|c|c|c|c|c|c|}
\hline \multirow{2}{*}{ Variabel } & \multirow{2}{*}{$\begin{array}{c}\text { Sub } \\
\text { Variabel }\end{array}$} & \multicolumn{3}{|c|}{ Faktor Komponen Teknologi IPLT } & \multirow{2}{*}{$\begin{array}{c}\text { Nilai } \\
\text { Maksimum }\end{array}$} & \multirow{2}{*}{ Keterangan } \\
\hline & & Faktor-1 & Faktor-2 & Faktor-3 & & \\
\hline \multirow{3}{*}{ Technoware } & $\mathrm{OLAH}$ & .212 & .950 & -.067 & .950 & \multirow{5}{*}{$\begin{array}{l}\text { Faktor-1: } \\
\text { KRIT, FUNG, ORG, } \\
\text { KelD, KiniD, } \\
\text { KEU,Mudak,Muham } \\
\text { Faktor-2: }\end{array}$} \\
\hline & KRIT & .625 & .605 & .114 & .625 & \\
\hline & FUNG & .838 & .090 & -.257 & .838 & \\
\hline \multirow{2}{*}{ Humanware } & JSDM & .550 & .785 & .029 & .785 & \\
\hline & KSDM & -.120 & .170 & .953 & .953 & \\
\hline \multirow{4}{*}{ Infoware } & KelD & .938 & .189 & .069 & .938 & OLAH, JSDM \\
\hline & KiniD & .856 & .481 & .153 & .856 & $\underline{\text { Faktor-3 }}$ \\
\hline & Mudak & .933 & .336 & -.056 & .933 & KSDM \\
\hline & Muham & .917 & .092 & -.264 & .917 & Nilai dan varians (\%): \\
\hline \multirow{3}{*}{ Orgaware } & ORG & .867 & .431 & .164 & .867 & Faktor-1: 6,093 $(50,778 \%)$ \\
\hline & KJSM & .014 & .915 & .315 & .915 & Faktor-2: 3,334 (27,784\%) \\
\hline & KEU & .751 & .028 & .543 & .751 & Faktor-3: 1,514 (12,618\%) \\
\hline
\end{tabular}

Sumber: Hasil analisa, 2015

Korelasi antara sub variabel dengan ketiga faktor komponen teknologi IPLT terindikasi dari tanda negatif atau positif dan nilai korelasi. Namun, hanya variabel humanware saja yang memiliki sub variabel yang berkorelasi positif dengan ketiga faktor komponen teknologi IPLT yaitu sub variabel kompetensi SDM (KSDM). Hal ini menimbulkan kerancuan seolah-olah faktor komponen teknologi IPLT hanya terwakili oleh variabel humanware. Untuk memastikan hal tersebut, dilakukan rotasi matrik komponen teknologi dan hasilnya disajikan pada Tabel 4 .

Hasil rotasi matrik komponen teknologi IPLT telah menghilangkan kerancuan sehingga masingmasing variabel yang berkorelasi positif dengan ketiga faktor telah terwakili. Variabel technoware diwakili oleh desain unit bangunan (KRIT) dan variabel humanware diwakili oleh jumlah SDM (JSDM). Variabel infoware diwakili oleh sub variabel kelengkapan SOP (KelD) dan kekinian SOP (KiniD), sedangkan variabel orgaware diwakili oleh ketiga sub variabelnya yaitu tugas dan tanggung jawab (ORG), kerjasama (KJSM) dan keuangan (KEU).

Faktor-1 terbentuk dari 8 sub variabel komponen teknologi IPLT (KRIT, FUNG, ORG, KelD, KiniD, Keu, Mudak dan Muham) dan memiliki nilai varians (eigenvalue) 6,093 (> 1,00) serta memiliki proporsi 50,778\% dari keragaman total. Faktor-2 terbentuk dari 2 (dua) sub variabel komponen teknologi IPLT (OLAH, JSDM) dan memiliki nilai varians (eigenvalue) 3,334 (>1,00) serta memiliki proporsi $27,784 \%$ dari keragaman total. 


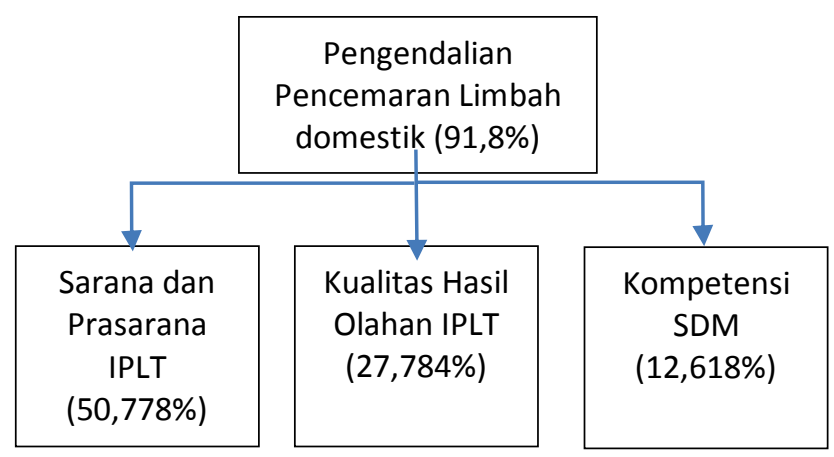

Gambar 2 Struktur Pengendalian Pencemaran Limbah domestik

Tabel 5 Bobot Faktor Komponen Teknologi IPLT

\begin{tabular}{|c|c|c|c|c|c|}
\hline \multirow{2}{*}{ IPLT } & \multicolumn{3}{|c|}{ Bobot Faktor (Bf) } & \multirow{2}{*}{ Bf Maks } & \multirow{2}{*}{$\%$ Total } \\
\hline & Faktor-1 & Faktor-2 & Faktor-3 & & \\
\hline Tegal & 0.464 & -0.208 & -2.019 & 0.464 & $9.8 \%$ \\
\hline Palu & -1.759 & 1.003 & 0.093 & 1.003 & $21.3 \%$ \\
\hline Mojokerto & -1.230 & 0.498 & -0.027 & 0.498 & $10.6 \%$ \\
\hline Banda Aceh & 0.442 & 0.106 & -1.286 & 0.442 & $9.4 \%$ \\
\hline Tangerang & -0.501 & -0.955 & 0.707 & 0.707 & $15.0 \%$ \\
\hline Klungkung & 0.270 & -0.108 & 0.399 & 0.399 & $8.5 \%$ \\
\hline Buleleleng & 0.528 & -0.686 & 0.526 & 0.528 & $11.2 \%$ \\
\hline Kulonprogo & 0.268 & -1.443 & 0.669 & 0.669 & $14.2 \%$ \\
\hline
\end{tabular}

Sumber: Hasil analisa, 2015

Faktor-3 hanya terbentuk dari 1 (satu) sub variabel komponen teknologi IPLT (KSDM) dan memiliki nilai varians (eigenvalue) 1,514 (> 1,00) serta memiliki proporsi $12,618 \%$ dari keragaman total.

Dengan demikian, maka struktur pengendalian pencemaran limbah domestik oleh IPLT Kota studi dapat dirangkum pada Gambar 2. Hasil tersebut memberi indikasi bahwa pengendalian pencemaran limbah domestik masih terfokus pada penyediaan sarana dan prasarana instalasi pengolahan air, tetapi belum memperhatikan kinerja pengolahan air untuk menghasilkan output hasil olahan (effluent) yang memenuhi standar effluent yang ditetapkan. Hal tersebut terbukti dari hasil penilaian status kualitas air limbah yang dialirkan ke badan air penerimanya. Dari 8 (delapan) IPLT yang dikaji, tidak ada satupun hasil olahan yang memenuhi standar.

Berdasarkan hasil pemeriksaan laboratorium terhadap parameter air limbah yang ditetapkan dalam Permen LH no 5 tahun 2014, hasil olahan IPLT untuk parameter $\mathrm{pH}$, Biochemical Oxygen Demand (BOD), Total Suspended Solid (TSS) serta minyak dan lemak dan setelah dikonversikan ke 154 dalam Indeks Kualitas Air (IKA), status kualitas olahan 4 (empat) IPLT yaitu IPLT Tegal, IPLT Palu, IPLT Buleleng dan IPLT Mojokerto termasuk kategori "cemar ringan". Status kualitas olahan limbah di 3 (tiga) IPLT lainnya yaitu IPLT Klungkung, IPLT Banda Aceh dan IPLT Tangerang termasuk kategori "cemar sedang" dan satu IPLT sisanya (IPLT Kulonprogo) termasuk kategori "cemar berat".

\section{Bobot faktor dan Skor Faktor Komponen Teknologi IPLT}

Analisis bobot faktor dan skor faktor ditujukan untuk memberi gambaran tingkat penting Infrastruktur IPLT dan tingkat penting variabel atau sub variabel komponen teknologi pembentuk infrastruktur IPLT yang dikaji. Bobot faktor diperoleh dari output analisis faktor. Hasil analisis bobot faktor (Bf) disajikan pada Tabel 5 sedangkan hasil analisis skor faktor disajikan pada Tabel 6 .

Pada Tabel 5 tersebut, bobot faktor maksimum IPLT Palu memiliki bobot faktor terbesar dengan proporsi $21,3 \%$ dari bobot faktor total maksimum. Bobot faktor terbesar kedua dimiliki oleh IPLT Tangerang dengan proporsi 
$15,0 \%$ dari total bobot faktor maksimum. Bobot faktor terbesar ketiga dimiliki IPLT Kulonprogo dengan proporsi $14,2 \%$ dari total bobot faktor maksimum. Berbeda dengan bobot faktor, skor faktor menunjukkan tingkat penting variabel dan sub variabel komponen teknologi IPLT, lihat Tabel 6.

Tampak pada Tabel 6 tersebut bahwa skor faktor sub variabel kompetensi SDM (KSDM) menempati urutan penting pertama dengan proporsi $20,3 \%$ dari total maksimum skor faktor. Sub variabel terpenting kedua adalah keuangan (KEU) dengan proporsi 12,9 dari total skor faktor maksimum. Sub variabel terpenting ketiga adalah kualitas hasil olahan (OLAH) dengan proporsi $12,8 \%$ dari total skor faktor maksimum.

\section{Kontribusi IPLT pada pengendalian pencemaran limbah domestik}

Ditinjau dari sudut pandang teknologi yang unsurnya meliputi technoware, humanware, infoware dan orgaware, kontribusi IPLT dapat dilihat dari jumlah IPLT yang dikaji dan sub variabel teknologi yang membentuk komponen teknologi IPLT. Penilaian ini bersifat tidak langsung atau menggunakan sub variabel teknologi sebagai acuan penilaian. Hasil estimasi terhadap kontribusi IPLT dirangkum pada Tabel 7.

Ditinjau dari sudut pandang infrastruktur, kontribusi IPLT Kota studi pada tujuan pengendalian pencemaran limbah domestik termasuk kategori “Cukup Optimal”. Sebanyak 6 (enam) IPLT atau 75\% termasuk kategori Cukup Optimal, sisanya 2 (dua) IPLT termasuk kategori "Kurang Optimal".

Penilaian tersebut tidak cukup lengkap apabila tidak dikaji unsur-unsur pembentuk komponen teknologi IPLT. Hasil penilaian terhadap sub variabel komponen teknologi menyimpulkan bahwa kontribusi IPLT termasuk ke dalam kategori kurang optimal, lihat Tabel 8.

Berdasarkan evaluasi terhadap kondisi infrastruktur dan sub variabel atau sub komponen teknologi pembentuk IPLT, maka kontribusi IPLT pada pengendalian pencemaran limbah domestik termasuk kategori "kurang optimal”, karena mempunyai nilai rata-rata $44.1 \%$.

Tabel 6 Skor Faktor Komponen Teknologi IPLT

\begin{tabular}{ccccccc}
\hline \multirow{2}{*}{ Sub Variabel } & \multicolumn{2}{c}{ Skor Faktor (Sf) Komponen IPLT } & \multirow{2}{*}{ Sf Maks } & \% Total \\
\cline { 2 - 4 } & Faktor-1 & Faktor-2 & Faktor-3 & & \\
\hline OLAH & -.125 & .409 & -.186 & .409 & $12.8 \%$ \\
KRIT & .042 & .148 & .012 & .148 & $4.6 \%$ \\
FUNG & .171 & -.071 & -.165 & .171 & $5.3 \%$ \\
JSDM & -.011 & .258 & -.079 & .258 & $8.0 \%$ \\
KSDM & -.022 & -.047 & .650 & .650 & $20.3 \%$ \\
ORG & .133 & .016 & .084 & .133 & $4.1 \%$ \\
KJSM & -.150 & .370 & .085 & .370 & $11.5 \%$ \\
KEU & .193 & -.206 & .413 & .413 & $12.9 \%$ \\
KelD & .190 & -.093 & .057 & .190 & $5.9 \%$ \\
KiniD & .121 & .043 & .069 & .121 & $3.8 \%$ \\
Mudak & .157 & -.005 & -.055 & .157 & $4.9 \%$ \\
Muham & .190 & -.083 & -.167 & .190 & $5.9 \%$ \\
\hline
\end{tabular}

Sumber: Hasil Analisa, 2015 
Tabel 7 Kontribusi Infrastruktur IPLT

\begin{tabular}{lcccc}
\multicolumn{1}{c}{ IPLT } & IPLT-R-Bf & IPLT-R-Sf & IPLT-R rata2 & Kontribusi \\
\hline Tegal & $53.7 \%$ & $37.2 \%$ & $45.5 \%$ & Kurang Optimal \\
Palu & $64.1 \%$ & $76.3 \%$ & $70.2 \%$ & Cukup Optimal \\
Mojokerto & $48.7 \%$ & $71.4 \%$ & $60.1 \%$ & Cukup Optimal \\
Banda Aceh & $45.5 \%$ & $57.3 \%$ & $51.4 \%$ & Cukup Optimal \\
Tangerang & $66.1 \%$ & $69.1 \%$ & $67.6 \%$ & Cukup Optimal \\
Klungkung & $58.6 \%$ & $56.9 \%$ & $57.8 \%$ & Cukup Optimal \\
Buleleleng & $64.1 \%$ & $60.3 \%$ & $62.2 \%$ & Cukup Optimal \\
Kulonprogo & $26.5 \%$ & $55.4 \%$ & $41.0 \%$ & Kurang Optimal \\
\hline Rata rata & $53.4 \%$ & $60.5 \%$ & $57.0 \%$ & Cukup Optimal \\
\hline
\end{tabular}

Catatan: 0-25 (tidak optimal); 26-50 (kurang optimal); 51-75 (cukup optimal);76-100 (optimal)

Sumber: Hasil analisa, 2015

Tabel 8 Kontribusi Komponen Teknologi IPLT

\begin{tabular}{|c|c|c|c|c|c|}
\hline Variabel & Sub Variabel & KTR-Bf & KTR-Sf & $\mathrm{KTR}_{\text {rata2 }}$ & Kontribusi \\
\hline \multirow{3}{*}{ Technoware } & OLAH & $28.4 \%$ & $74.9 \%$ & $51.6 \%$ & Cukup Optimal \\
\hline & KRIT & $25.0 \%$ & $64.6 \%$ & $44.8 \%$ & Kurang Optimal \\
\hline & FUNG & $16.9 \%$ & $56.5 \%$ & $36.7 \%$ & Kurang Optimal \\
\hline \multirow{2}{*}{ Humanware } & JSDM & $21.3 \%$ & $54.1 \%$ & $37.7 \%$ & Kurang Optimal \\
\hline & KSDM & $39.1 \%$ & $82.7 \%$ & $60.9 \%$ & Cukup Optimal \\
\hline \multirow{4}{*}{ Infoware } & KLd & $0.0 \%$ & $66.3 \%$ & $33.1 \%$ & Kurang Optimal \\
\hline & KiniD & $0.0 \%$ & $75.0 \%$ & $37.5 \%$ & Kurang Optimal \\
\hline & Mudak & $0.0 \%$ & $78.7 \%$ & $39.3 \%$ & Kurang Optimal \\
\hline & Muham & $0.0 \%$ & $88.3 \%$ & $44.2 \%$ & Kurang Optimal \\
\hline \multirow{4}{*}{ Orgaware } & ORG & $20.1 \%$ & $65.0 \%$ & $42.5 \%$ & Kurang Optimal \\
\hline & KJSM & $27.4 \%$ & $71.4 \%$ & $49.4 \%$ & Kurang Optimal \\
\hline & KEU & $35.0 \%$ & $67.4 \%$ & $51.2 \%$ & Cukup Optimal \\
\hline & Rata rata & $17.8 \%$ & $70.4 \%$ & $44.1 \%$ & Kurang Optimal \\
\hline
\end{tabular}

Catatan: 0-25 (tidak optimal); 26-50 (kurang optimal); 51-75 (cukup optimal); 76-100 (optimal)

Sumber: Hasil analisa, 2015

IPLT, pada dasarnya dibangun untuk mereduksi bangkitan beban cemaran yang berasal dari kawasan permukiman. Kontribusi IPLT pada pengendalian limbah domestik dapat diestimasi dari laju beban cemaran yang dapat direduksi persatuan waktu dalam $\mathrm{g} / \mathrm{hari}$ atau $\mathrm{kg} /$ hari atau ton/tahun. Oleh karena itu, laju reduksi beban cemaran merupakan perkalian antara volume limbah tinja yang diolah $\left(\mathrm{m}^{3} /\right.$ hari $)$ dengan kandungan beban cemaran (mg/liter) di dalam limbah tinja tersebut.

Estimasi tersebut penting untuk memantau perkembangan dan status kualitas hasil olahan, tetapi belum memberi arah bagaimana memperbaiki kontribusi IPLT pada pengendalian pencemaran limbah domestik. Analisis faktor mampu memberi arahan bagian mana dari komponen teknologi IPLT yang harus diperbaiki. Sebagaimana tertera pada Tabel 8, nilai 
kontribusi terkecil pada unsur technoware adalah sub variabel Fungsi IPLT (FUNG). Nilai kontribusi terkecil pada variabel humanware adalah sub variabel jumlah SDM (JSDM). Nilai kontribusi variabel infoware adalah sub variabel kelengkapan dokumen atau SOP (KelD). Nilai kontribusi terkecil variabel orgaware adalah organisasi (ORG). Nilai kontribusi sub variabel terkecil memberi indikasi tentang arah prioritas perbaikan kualitas olahan IPLT yang perlu dilakukan.

Sub variabel fungsi IPLT pada unsur technoware berhubungan dengan jadwal pengurasan limbah tinja dari tangki septik yang harus dikirim ke IPLT. Pasokan limbah tinja yang tidak terjadwal berakibat pada minimnya volume limbah tinja yang diolah sehingga meningkatkan laju beban pencemaran yang memasuki perairan tanpa melalui pengolahan yang semestinya.

Minimnya volume limbah yang dikirim ke IPLT dipengaruhi oleh jumlah SDM yang seharusnya ikut terlibat untuk memaksimalkan volume pasokan limbah tinja belum memadai. SDM yang terlibat, tidak hanya operator di bangunan instalasi saja, tetapi juga SDM yang mengatur jadwal pengurasan tangki septik, memantau kondisi trafik pada rute Jalan menuju ke IPLT, mencatat jumlah ritasi truk tinja dan keterlibatan SDM lainnya.

Belum memadainya jumlah SDM yang terlibat dipengaruhi oleh pembagian tugas dan tanggungjawab yang belum jelas. Pengoperasian IPLT tidak hanya tanggung jawab operator saja, tetapi juga menjadi tanggungjawab masyarakat yang dilayani IPLT. Oleh karena itu, bagian mana saja yang menjadi tugas dan tanggungjawab operator, pembina organisasi, mitra swasta dan masyarakat yang dilayani IPLT. Hal ini sejalan dengan hasil penelitian Nyayu, 2014, yang menyatakan bahwa analisa kelembagaan dengan Fishbein dan SWOT, pengelolaan IPLT belum efektif dalam hal pelayanan dan operasional. Saran kinerja pengelola IPLT dengan menyediakan tenaga kerja ahli limbah di Kantor Kebersihan dan Pertamanan Kota Prabumulih melalui pelatihan. Sedangkan, berdasarkan hasil kajian pustaka di beberapa IPLT dengan sosialisasi ke masyarakat melalui penyebaran pamflet untuk informasi sedot tinja.

Tanggungjawab masyarakat juga tidak hanya terbatas pada pembayaran retribusi saja, tetapi juga ikut memantau dan memberi umpan balik tentang kualitas pelayanan dan kondisi lapangan yang berpotensi mengganggu jalannya pengoperasian tangki septik, sarana penyedotan dan sarana transportasi. Mitra kerja dan masyarakat mempunyai peran yang cukup signifikan dalam memantau hasil kerja yang dilakukan sesuai SOP.

\section{KESIMPULAN}

Aplikasi analisis faktor terbukti mampu dipakai sebagai instrumen pengambilan keputusan untuk meningkatkan upaya pengendalian pencemaran limbah domestik di sumber pencemaran. Analisis faktor mampu mereduksi 12 (dua belas) sub variabel menjadi 3 (tiga) faktor, sehingga proses analisis menjadi lebih sederhana tanpa mengurangi makna indikator pembentuknya sehingga mempermudah proses pengambilan keputusan. Pasokan lumpur tinja terjadwal; kejelasan pembagian tugas dan tanggung jawab; ketersediaan, kekinian, kemudahan akses dan kemudahan memahami SOP menjadi faktor penentu keberhasilan IPLT dalam pengendalian pencemaran limbah domestik. Upaya yang dapat dilakukan adalah: (1) memperbaiki pola pasokan limbah tinja, (2) menambah SDM yang melaksanakan proses pengendalian pencemaran limbah domestik berbasis IPLT, (3) mempertegas pembagian tugas dan peran serta tanggungjawab yang jelas dalam kelembagaan IPLT, serta (4) ketersediaan SOP yang selalu diperbaharui sesuai perkembangan lapangan, harus mudah diakses dan mudah dipahami isinya oleh pengguna.

\section{DAFTAR PUSTAKA}

Abbas Toloui, Yachoub Alawi Matin. 2012. Measuring Technological Level and Capability of the Industries in East Azerbaijan and Providing Proper Strategies for Improvement and Promotion of Technology, Journal of Basic and Applied Scientific Research 2(4) 2012: 3664-3669.

Hanien Nia H Shega, Rita Rahmawati, Hasbi Yasin. 2012. Penentuan Faktor Prioritas Mahasiswa dalam Memilih Telepon Seluler Merk Blackberry dengan Fuzzy AHP, Jurnal Gaussian Vol 1, No 1 (2012): 73-82.

Iwan Inrawan Wiratmadja, Rajesri Govindarayu, Evy Setiawati, 2011. Analysing the Influence of Technology on the Business Performance of Rattan Processing SME's in South Kalimantan, IEMS vol 1 no 2, June 2011: 104-108.

Kamaladdin Rahmani, Mahmood Behravesh, Masoud Bahravesh, Nayere Karegar, Abolfazl Fereidononi. 2010. Examining, the Level and Strengths of Technology in the Industries of the Country Iran by Using Escap Model and Introducing Solution fo Developing Technology, Australian Journal of Basic and Applied Science, 4(10) 2010: 4638-4649. 
Jurnal Sumber Daya Air Vol.11 No. 2, November 2015: 147 - 158

Kementerian Kesehatan. 2013. Profil Kesehatan Indonesia 2012.

M Despeesse, F Mbaye, PD Ball, A lever. 2011. The Emergence of Sustainable Manufacturing Practices, Production Planning \& Control: The Management of Operations, vol. 23, no. 5, 2011: 354-376

Maryam Ebrahimi, Abbas Moghbel Baerz, Seyed Hamid Khodadad Hosseimi, Adel Azar. 2013. A New Technology Assessment: A Case Study of Iran Petrocemical Industries, International Journal of Humanities vol 20(3), 2013: 27-51.

Mohammad Reza, Kabaranzad Ghadim, Babak Sohrabi. 2011. Recocnation and Selection of Optimal Method for Transferring Technology in Tehran Gas Organization, Journal of Science and Technology vol 4 No 9, Sep 2011: 11291136.

Nyayu Mariam. 2014. Kajian Kinerja Instalasi Pengolahan Lumpur Tinja (IPLT) (Studi Kasus IPLT Sungai Medang Kota Prabumulih), Tesis Teknik SIpil UGM.

Pamekas, R. 2013. Pembangunan dan Pengelolaan Infrastruktur Kawasan Permukiman, Penerbit Pustaka Jaya, Bandung: 181-193.
Puslitbang Permukiman. 2013. Laporan Akhir: Kegiatan Pengembangan Teknologi Instalasi Pengolahan Lumpur Tinja.

Retno Indriartiningtias, Resta Amijaya, Widi Nugroho. 2014. Penilaian Teknologi 2 Industri Pembuat Skop dengan Metode Teknometrik, Jurnal Metris 15 2014: 89-96.

Sarono, E Gumbira Said, Ono Suparno, Suprihatin, Udin Hasanudin. 2014. Evaluation of Technological Content of Wastewater Treatment of Palm Oil Mill in Lampung Province, Indonesia, Environment Asia 7(1), 2014: 39-44

\section{UCAPAN TERIMA KASIH}

Kepada Prof. (R) DR. Ir. R. Pamekas, M.Eng yang telah memberi arahan dan bimbingan selama penyusunan KTI ini, penulis mengucapkan terima kasih yang sebesar besarnya. 